\title{
ANALYSIS OF WHEAT PRODUCTION IN THE REPUBLIC OF NORTH MACEDONIA FROM 2016 - 2019
}

\author{
Aleksandra Angeleska ${ }^{1}$, Risto Uzunov ${ }^{2}$, Radmila Crceva Nikolovska ${ }^{3}$, \\ Elizabeta Dimitrieska Stojkovik ${ }^{4}$, Katerina Blagoevska ${ }^{5}$, Biljana Dimzoska Stojanovska ${ }^{6}$ \\ *Corresponding author E-mail: mizasandra@yahoo.com
}

\begin{abstract}
A R T I C L E I N F O
A B S T R A C T

Original Article

Received: 08 April 2021

Corn, wheat and other different types of cereal crops, are one of the basic nutritional products in general, which have essential and vast application in the daily diet of people around

Accepted: 31 July 2021

doi:10.5937/ekoPolj2103675A

UDC 631.15:633.11(497.11)"20 16/2019" the world. Cereal crops are the most important food sources, and cereal-based food is the main source of energy, protein, $\mathrm{B}$ vitamins and minerals for the world population. Therefore, the goal of this research is to analyze the production of wheat on arable land in the Republic of North Macedonia,

Keywords:

analysis, wheat production, North Macedonia as an agricultural country, which will indirectly help to draw conclusions about the impact on the economic structure of the population, their standard of living, the investment and economic fluctuations in market prices, taken as a sui generis

JEL:Q10 element, set as an assumption ceteris paribus against the other determinants and factors that affect the national economy in the Republic of North Macedonia.
\end{abstract}

(C) 2021 EA. All rights reserved.

1 Aleksandra Angeleska, researcher, Faculty of Veterinary Medicine, Lazar Pop Trajkov 5-7, Skopje, North Macedonia, Phone: +38971332569, E-mail: mizasandra@yahoo.com, (https://orcid.org/ 0000-0002-7109-2681)

2 Risto Uzunov, Assistant professor, Faculty of Veterinary Medicine, Lazar Pop Trajkov 5-7, Skopje, North Macedonia, Phone: +38970316319, E-mail: risteuzunov@,fvm.ukim.edu. mk, ORCID ID (https://orcid.org/0000-0002-4901-1312)

3 Radmila Crceva Nikolovska, associate professor, Faculty of Veterinary Medicine, Lazar Pop Trajkov 5-7, Skopje, North Macedonia, Phone: +38970232282, E-mail: rnikolovska@ fvm.ukim.edu.mk, ORCID ID (https://orcid.org/ 0000-0002-8978-7238)

4 Elizabeta Dimitrieska Stojkovic, senior research associate, Faculty of Veterinary Medicine, Lazar Pop Trajkov 5-7, Skopje, North Macedonia, Phone: +39870222049, E-mail: edimitrieska@fvm.ukim.edu.mk, ORCID ID (https://orcid.org/ 0000-0001-8315-5267)

5 Katerina Blagoevska, senior research associate, Faculty of Veterinary Medicine, Lazar Pop Trajkov 5-7, Skopje, North Macedonia, Phone: +38975456636, E-mail: katerinab@,fvm. ukim.edu.mk, ORCID ID (https://orcid.org/ 0000-0003-0535-6025)

6 Biljana Dimzoska Stojanovska, senior research associate, Faculty of Veterinary Medicine, Lazar Pop Trajkov 5-7, Skopje, North Macedonia, Phone: +38970779955, E-mail: bsdimzoska@yahoo.com, ORCID ID (https://orcid.org/ 0000-0003-3252-6034)

http://ea.bg.ac.rs 


\section{Introduction}

Corn, wheat and other different types of cereal crops, are one of the basic nutritional products in general, which have essential and vast application in the daily diet of people around the world. From time immemorial, when the human didn't have any developed refined tastes or methods of food processing such as the ones that are available to us today, cereal crops have been one of the basic food products on the table. Cereal crops can be defined as the grain or seed of the family of grasses Gramineae (Bender and Bender,1999; McKevith, 2004)

In addition to being used for human consumption, cereal crops, such as oats, wheat and barley, also constitute the basic diet for livestock, which is being raised in order to process various types of meat and meat products, as well as for milk and dairy products. Thereby cereal crops are again, this time indirectly, the basis of human nutrition. By manipulating different types of cereal crops, the human has learned that livestock can reach greater weight in a shorter period of time when being fed with cereal crops (a fact that the entire basis of stockbreeding rests on). This again leads to an indirect correlation with the production of cereals. Based on all abovementioned, cereal crops are the most important food sources (FAO 2002), and cereal-based food is the main source of energy, protein, B vitamins and minerals for the world population. (FAO, 2002).

In modern dietary trends as well, which in recent years are increasingly becoming more popular (vegetarianism, veganism, etc.), and are based on the exclusion of meat and dairy products in the daily diet, cereal crops, in addition to vegetables and fruits, are increasingly becoming more important as a major source of nutrients, but also a source of fibers which are the basic structural units of every cereal crop. Cereals are strategically important and the most grown crops, but the country does not produce enough to meet the domestic needs. (National programme for agriculture and rural development 2007-2013, 2007).

In our region, the Republic of North Macedonia, as well as in the Balkans in general, pastries and bread (mainly made from wheat grain) are still the basic products on the table in the daily diet. For a national economy to be stable and prosperous, it is necessary to meet the basic needs of the citizens as well as most of the basic products in the "basket of consumer goods of the household" by means of the country's own production resources. Hence, the production of milk, dairy products and wheat, sufficient to meet the needs of the country's population, is one of the fundamental postulates of agricultural economics as a part of the overall national economy in the Republic of North Macedonia.

Therefore, the goal of this research is to analyze the production of wheat on arable land in the Republic of North Macedonia, as an agricultural country, which will indirectly help to draw conclusions about the impact on the economic structure of the population, their standard of living, the investment and economic fluctuations in market prices, taken as a sui generis element, set as an assumption ceteris paribus against the other determinants and factors that affect the national economy in the Republic of North Macedonia. 


\section{Methodological framework}

For the needs of this paper, a number of scientific papers from different fields have been read and analyzed, especially in the field of agricultural economics, agriculture and economy in general. The findings and final results presented in this paper are the result of induction and deduction, as well as the synthesis and analysis of numerous pieces of information, and descriptive statistics, comparative analysis and correlation analysis.

According to the geographical position, the Republic of North Macedonia is located between $40^{\circ} 51^{\prime}$ and $42^{\circ} 22^{\prime}$ north latitude, and between $20^{\circ} 27^{\prime}$ and $23^{\circ} 02^{\prime}$ east longitude. According to these geographical parameters, the country is located in the southern part of the temperate zone and is bordered by the sub-tropical climate zone, which allows the production of a large number of crops. (Smith, 2003). The Republic of North Macedonia has 280 sunny days annually on average, which makes it the second in the world with the so-called highest quality "solar energy peak" (the so-called "peak of solar energy" in the Republic of North Macedonia reaches from 1380 to 1520 kilowatt hours of solar radiation per square meter). The favorable geographic position and the mild continental and Mediterranean climate contribute to the production of cereal crops and wheat to become one of the basic production branches, as well as an ideal profession for many entrepreneurs and investors (domestic and foreign), individual farmers and hired workers. In the Republic of North Macedonia, agriculture has a key role in the development of the national economy, as the third largest sector, just behind catering and industry. The total share of agriculture as a sector in the GDP of our country has been increasing continuously, i.e. in 2016 it amounted to 885.8 million Euros, in 2017 it was 790.3 million Euros, which is recorded as the only decline in the share of agriculture as a branch in GDP, mainly due to poor weather conditions, then, in 2018 it was 901.9 million Euros, and in 2019 it reached 910.9 million Euros.

According to the data of the State Statistical Office (SSO), agricultural land covers approximately 1.266 thousand hectares, which is $49 \%$ of the total area of the Republic of North Macedonia. Of this area, almost half is arable land, and the other half is used for pastures.

Table 1. Participation of agriculture as a sector in the national economy

\begin{tabular}{|l|c|c|c|c|}
\hline Indicator & 2016 & 2017 & 2018 & 2019 \\
\hline $\begin{array}{l}\text { Gross value added } \\
\text { (GVA) of agriculture }\end{array}$ & $\begin{array}{c}885,8 \\
\text { million Euros }\end{array}$ & $\begin{array}{c}790,3 \\
\text { million Euros }\end{array}$ & $\begin{array}{c}901,9 \\
\text { million Euros }\end{array}$ & $\begin{array}{c}910,9 \\
\text { million Euros }\end{array}$ \\
\hline $\begin{array}{l}\text { Participation in the } \\
\text { gross domestic } \\
\text { product (GDP) }\end{array}$ & 9,1 & 7.9 & 8,5 & 8,1 \\
\hline
\end{tabular}

Source: MakStat (available at: http://www.stat.gov.mk/Default.aspx)

Of the agricultural arable land, gardens and arable lands sown with cereal crops have the highest share. Although the exact number varies each subsequent year, there is no significant percentage difference i.e. there is no drastic decline in the production of 
cereal crops compared to, for example, the production of garden crops, therefore in 2017, the total number of arable agricultural lands sown with cereal crops amounted to 167.623 hectares, which is about $33 \%$ of the total arable land in the Republic of North Macedonia. The most cultivated and most represented cereal crop in the Republic of North Macedonia is wheat, which from a statistical point of view, and by comparative analysis throughout the years, occupies about $40 \%$ of the total agricultural area sown with cereal crops. (Agrounija, 2019). The largest quantities of wheat and the largest number of agricultural arable land sown with wheat, have always been in the Pelagonija region of the Republic of North Macedonia, in the Pelagonija valley, which is spread in the southwest part of the country. According to the data summarized in the National Strategy for Agriculture and Rural Development 2014 - 2020, the Pelagonija region stands out as a region with the most significant share in the GDP in agricultural production, with a significant 21\%. (Republic of North Macedonia, 2014)

Table 2. Arable land in the Republic of North Macedonia in the period from $2011-2018$

\begin{tabular}{|l|c|c|c|c|c|c|c|c|}
\hline Pointer & 2011 & 2012 & 2013 & 2014 & 2015 & 2016 & 2017 & 2018 \\
\hline Agricultural Land & 1.12 & 1.268 & 1.261 & 1.263 & 1.264 & 1.267 & 1.266 & 1.264 \\
\hline Arable Lands & 511 & 510 & 509 & 511 & 513 & 516 & 517 & 519 \\
\hline $\begin{array}{l}\text { Arable Lands and } \\
\text { Gardens }\end{array}$ & 4.15 & 414 & 413 & 413 & 415 & 417 & 417 & 418 \\
\hline Orchards & 14 & 15 & 15 & 15 & 16 & 16 & 16 & 17 \\
\hline Vineyards & 21 & 21 & 22 & 23 & 23 & 24 & 24 & 24 \\
\hline Meadows & 61 & 60 & 59 & 60 & 60 & 59 & 60 & 60 \\
\hline Graizing areas & 608 & 757 & 751 & 751 & 750 & 750 & 748 & 745 \\
\hline $\begin{array}{l}\text { Ponds, Reeds and } \\
\text { Fishponds }\end{array}$ & 1 & 1 & 1 & 1 & 1 & $/$ & 1 & 1 \\
\hline
\end{tabular}

Source: State Statistical Office

By analyzing the producers of wheat in the Republic of North Macedonia, if we make a deductive analysis of the chart presented below, we could come to the conclusion that these are rather individual farmers and small agricultural holdings. Large agricultural holdings are less and less common, hence we can summarize that most of the agricultural holdings in our country are tiny, small and non-commercial, as well as individual farmers as independent agricultural economic entities, according to the Law on Agricultural Activity. In the table below, you can see quarterly data on the purchase of agricultural products, which in the Republic of North Macedonia is performed mostly by individual agricultural producers, as well as data on the purchase of wheat, given by months for 2019, therefore one can conclude that mostly individual agricultural producers are engaged in the production of this cereal crops. 
Table 3. Purchase and sale of agricultural products, by months, quarterly report

\begin{tabular}{|c|c|c|c|}
\hline & VII 2019 & VII 2019 & IX 2019 \\
\hline Total purchase & $\begin{array}{c}1.267 .508,00 \\
\text { tons }\end{array}$ & $\begin{array}{c}1.189 .054,00 \\
\text { Tons }\end{array}$ & $\begin{array}{c}1.815 .441 \\
\text { tons }\end{array}$ \\
\hline $\begin{array}{c}\text { Purchase from individual } \\
\text { agricultural producers }\end{array}$ & $\begin{array}{c}\text { t57.724,00 } \\
\text { tons }\end{array}$ & $\begin{array}{c}651.283,00 \\
\text { Tons }\end{array}$ & $\begin{array}{c}1.127 .076 \\
\text { tons }\end{array}$ \\
\hline $\begin{array}{c}\text { Purchase and sale of wheat } \\
\text { and rye }\end{array}$ & $\begin{array}{c}26.977,00 \\
\text { tons }\end{array}$ & $\begin{array}{c}16.899,00 \\
\text { Tons }\end{array}$ & $\begin{array}{c}2.016 \\
\text { tons }\end{array}$ \\
\hline
\end{tabular}

Source: MakStat report no.5.1.20.14

Table 4. Areas and production of cereal crops in the Republic of North Macedonia in the period from 2016, 2017 and 2018

\begin{tabular}{|c|c|c|c|}
\hline & $\mathbf{2 0 1 6}$ & $\mathbf{2 0 1 7}$ & $\mathbf{2 0 1 8}$ \\
\hline Sown areas (in ha) & & & \\
\hline Cereal crops & 165,459 & 161,289 & 166,664 \\
\hline Wheat & 79,898 & 72,965 & 73,072 \\
\hline Production (in tons) & & & \\
\hline Wheat & 306,433 & 200,112 & 241,106 \\
\hline Yield (t/ha) & & & 3,4 \\
\hline Wheat & 3,8 & 2,7 & \\
\hline
\end{tabular}

Source: State Statistical Office

By analyzing the data contained in Table 3, we can conclude that in 2017 there was a downward trend in terms of the representation of wheat and cereal crops in general in the domestic production. Wheat production in 2017 amounted to about 200.112 tons, which is a decrease by as much as approximately $35 \%$ compared to 2016 , which is certainly a result of reduced average yield per hectare by about $28 \%$, and reduced areas under wheat plantations by about $9 \%$ compared to those in 2016 . On the other hand, in 2018, wheat production has evidently increased and amounted to 241.106 tons, which is an increase by about $21 \%$ compared to the so-called "bad" 2017 , and it is in direct linear proportional correlation with the increased average yield per hectare which is $23.7 \%$, i.e. the increased areas planted with wheat. The line of wheat import is inversely proportional to these upward lines of increase in wheat production.

In terms of import, in 2017 the import of wheat in the Republic of North Macedonia increased by as much as 51.7\% (State Report on Agriculture and Rural Development for 2017 - Ministry of Agriculture, Forestry and Water Economy), i.e. a total of 4.4 million Euros were allocated from the state budget for the import of this good, which is by 1.5 million Euros more than the previous year, when we spent a total of 2.9 million Euros on wheat imports. As a consequence of the increased production of wheat in the next year, in 2018 there was a decrease in wheat import - from 4.4 million Euros to only 1.8 million Euros, which is a decrease in wheat import by an incredible $59 \%$ compared to the previous year. If, statistically observed from the presented data, we take 2017 as a "bad year" for wheat production, where we increased import by $51.7 \%$, the fact that the 
following year we reduced import by 59\%, puts the Republic of North Macedonia in an arbitrary economic situation, because not only have we covered the negative balance in terms of wheat production and the dependence on the imports from the previous year, but also, compared to the purchase price of wheat, which grew in 2018 and 2019, this positively affected its own market with the increased production, i.e. instead of reducing the price due to the increased production, the price of wheat grain increased despite its increased production. In 2019, wheat was sown on approximately 70.500 hectares, and the average yield per hectare was about 3.5 tons, depending on the region, which is an increase by about $4 \%$ compared to 2017 . The low yield of wheat in 2017 , as well as cereals in general was due to the unfavorable weather conditions, which contributed to the decline of the average annual purchase price of wheat in 2017 by $2.8 \%$ compared to the prices in 2016 , that is, from 9.09 denars per kilogram it reduced to 8.84 denars per kilogram of wheat grain.

Figure 1. Average purchase price (in denars) of wheat in 2016/2017

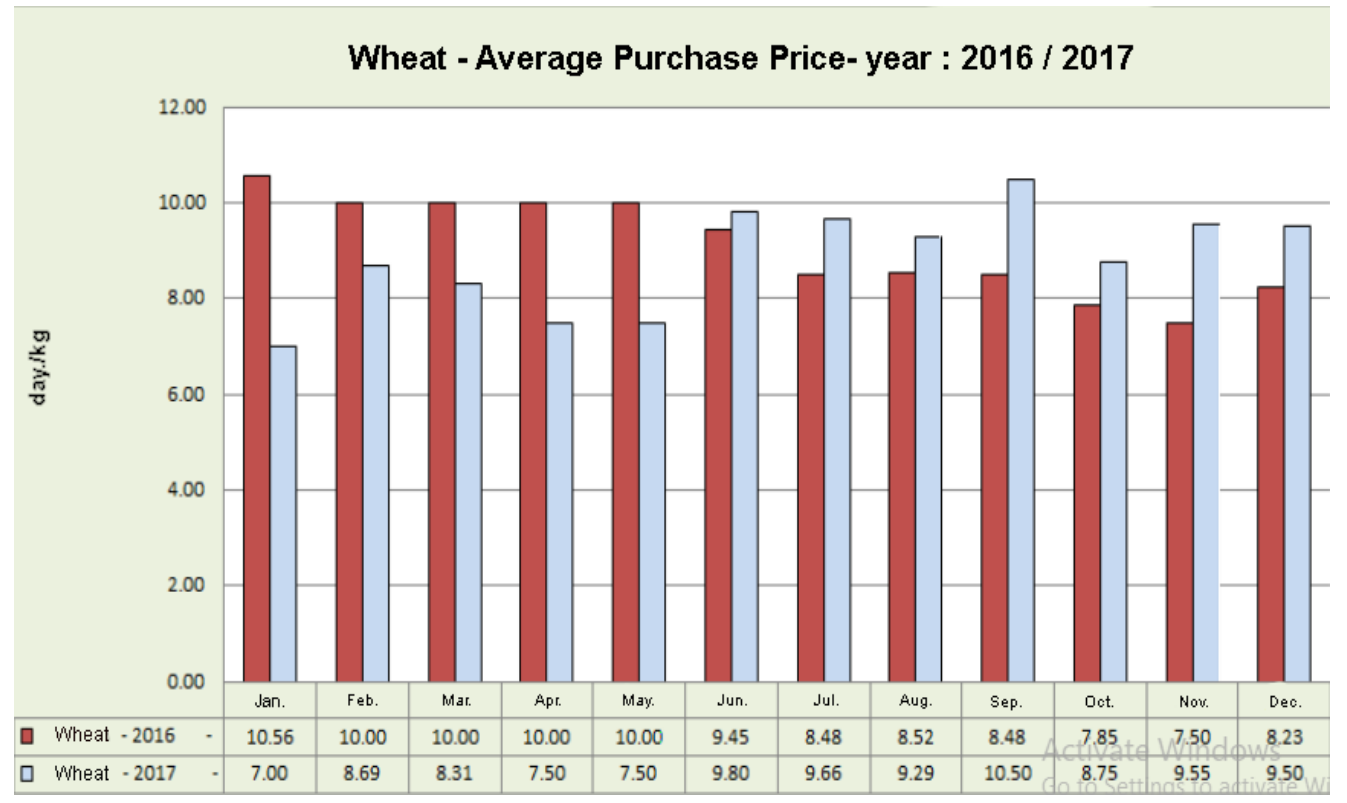

Source: Agricultural Market Information System 
Figure 2. Average purchase price (in denars) of wheat in 2017/2018 - Agricultural Market Information System

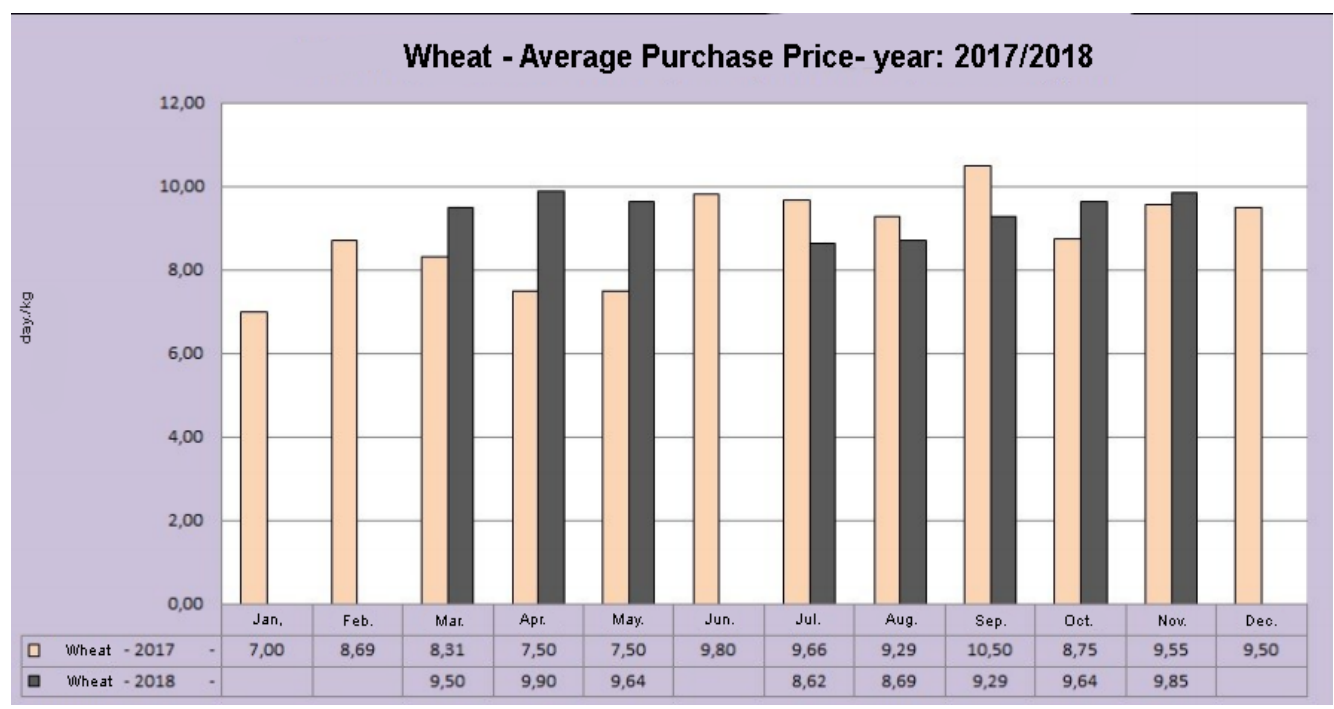

Source: Agricultural Market Information System (AMIS), Retrived from: http://zpis.gov.mk/

By analyzing the results from Graph 1, it can be concluded that the average purchase price of wheat grain in 2018 was 9.39 denars per kilogram, which compared to the price in 2017, which was 8.84 denars per kilogram of wheat on average, is an increase of the wheat grain price by $6.2 \%$. In addition, by analyzing the time continuity and prices, we can conclude that by the end of the year, there is an absolute increase in the purchase price of wheat grain, i.e. in January 2017, the price was 7.00 denars per kilogram, while in December of the same year - 9.50 denars per kilogram, which is a significant increase, probably because in December there is no domestic wheat for purchase. 
Figure 3. Average purchase price (in denars) of wheat in the period 2018/2019

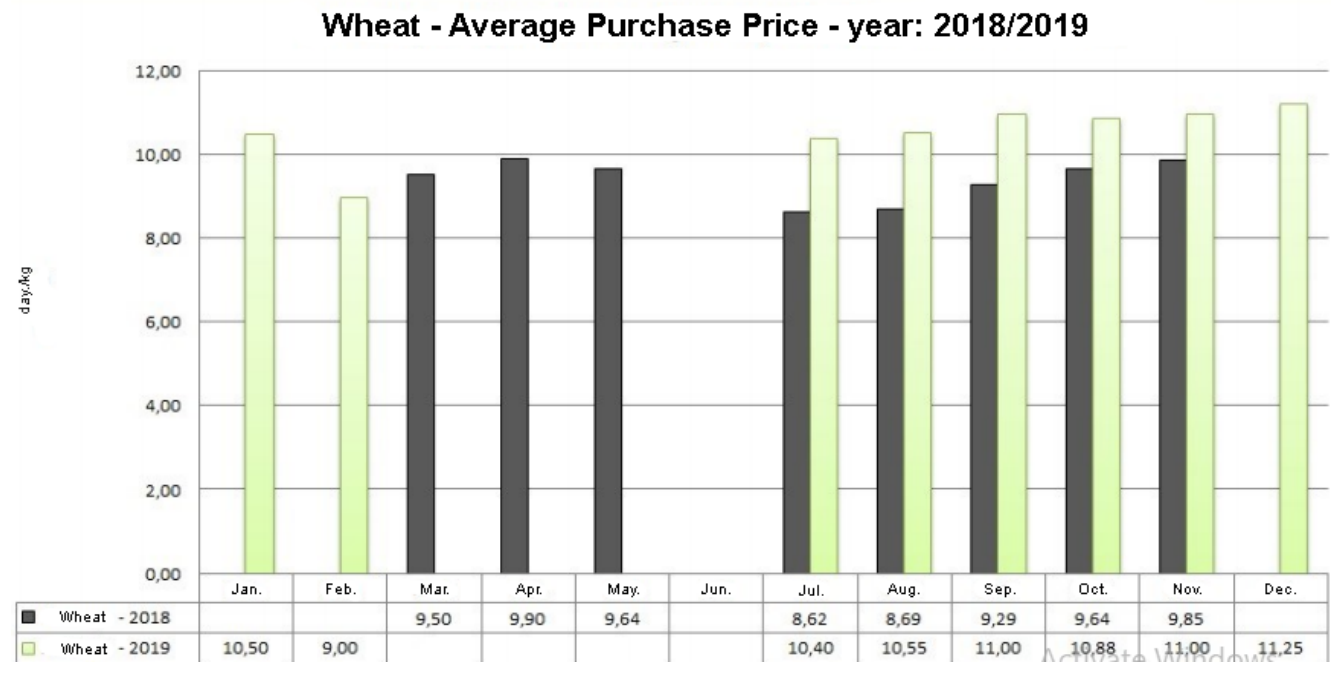

Source: Agricultural Market Information System (AMIS), Retrived from: http://zpis.gov.mk/

The purchase price of wheat tends to increase, i.e. in 2019 until December it was 10.85 denars per kilogram, which, compared to the average purchase price with the harvest of 2018, which was 9.39 denars per kilogram, is an increase of the price by about $12.6 \%$.

By summarizing the analyzed data, we can conclude that, not looking at the results of 2017, by isolating this year due to bad weather conditions for the entire agriculture, and not only for wheat and cereal crops, we can say that in the Republic of North Macedonia there is a visible tendency to increase wheat production, and this interest is particularly increasing among individual agricultural producers, whose number is constantly growing, and also due to the increased purchase price per wheat grain, which is also on the rise. For this reason, the Republic of North Macedonia does not need to import wheat, and moving at this pace, the export of wheat grain can only be increased. These favorable factors are also observed in other crops, a characteristic that is due to favorable production conditions, dictated by the favorable geographic and climate position, as well as the agricultural development policies, the European Union investment funds, integrated in our society through the Agency for Financial Support of Agriculture and Rural Development and the IPARD funds ${ }^{7}$ provided by the European Union.

An additional step forward was made on 17.12.2005 with the acquisition of candidate status for membership in the Union, which contributed for this country to gain access to the Instrument for Pre-Accession Assistance (IPA).

7 Instrument for Pre-Accession Assistance for Rural Development 
Table 5. Areas and production of cereal crops in the Republic of North Macedonia in the period from 2011 to 2015

\begin{tabular}{|l|c|c|c|c|c|}
\hline & $\mathbf{2 0 1 1}$ & $\mathbf{2 0 1 2}$ & $\mathbf{2 0 1 3}$ & $\mathbf{2 0 1 4}$ & $\mathbf{2 0 1 5}$ \\
\hline Sown areas (in ha) & & & & & \\
\hline Cereal crops & 160,994 & 161,126 & 166,436 & 160,988 & 159,434 \\
\hline Wheat & 78,588 & 79,750 & 81,756 & 76,861 & 73,979 \\
\hline Production (in tons) & & & & & \\
\hline Wheat & 256,103 & 214,963 & 258,960 & 287,594 & 201,218 \\
\hline Yield (t/ha) & & & & & \\
\hline Wheat & 3,35 & 2,7 & 3,2 & 3,76 & 2,75 \\
\hline
\end{tabular}

Source: Annual Agricultural Report 2015, https://www.stat.gov.mk/pdf/2021/5.1.21.03_mk.pdf

Figure 4. Distribution of IPARD investment funds in millions of Euros (European Commission. 2012. Multiannual Indicative Financial Frame)

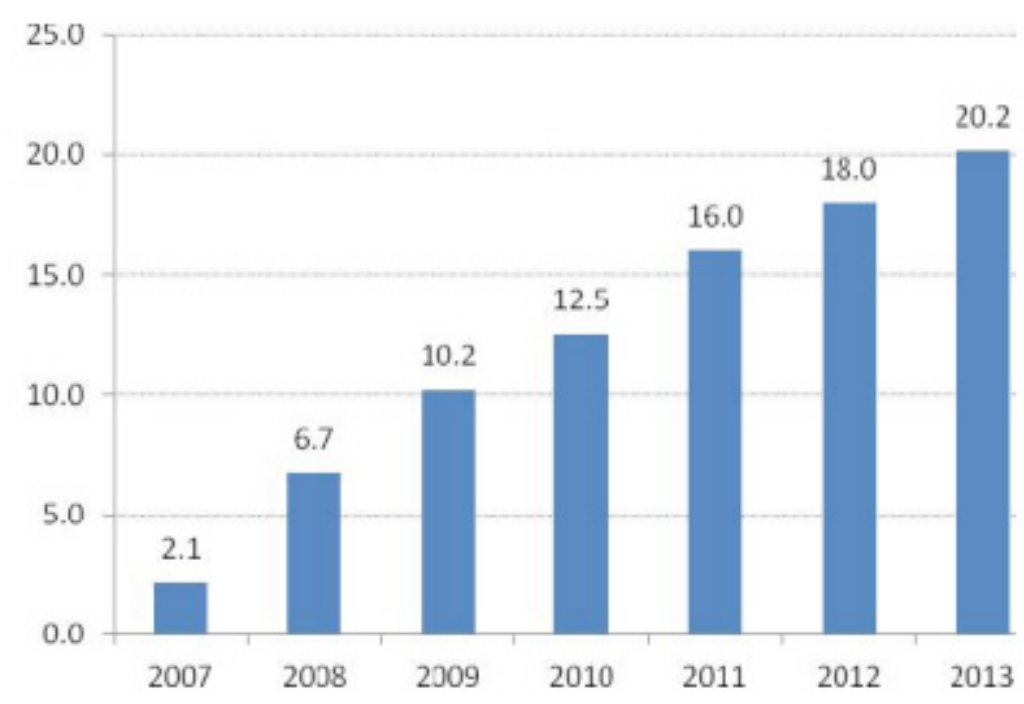

Source: Kovachev, 2013

The European perspective of the Macedonian agriculture and rural development started on 09.04.2001 with the conclusion of the Stabilization and Association Agreement of the Republic of Macedonia with the European Union (EU) which, among other things, liberalized trade and enabled an asymmetric trade regime in the trade in agricultural products for the benefit of Macedonia (except for the so-called "sensitive products") in a transition period of 10 years.

In Graph 4 it can be seen that with the inflow of the IPARD funds and their availability to agricultural producers across the country, the interest for their use has been growing rapidly, and logically and normally, the interest for engaging in agriculture as a branch has been growing as well, which is becoming more profitable, and at the same time, http://ea.bg.ac.rs 
agriculture is expanding and simplifying, thanks to access to more funds. It can be noticed that in the period from 2007 to 2013 the inflow of the IPARD funds in our country increased by an incredible $90 \%$. Accordingly, in the context of our central interest in this topic, we can conclude that although there is no vast increase in wheat production, investments are made in simplified ways of production and agricultural mechanization, as well as in purchase and production, i.e. in creating varieties of wheat grain of better quality - and our country has been extremely successful in this field. One of the leading companies in the Republic of North Macedonia - has produced several varieties of wheat that provide quality and increased production, some of which include the following: (Zelena berza, 2016)

- Agrounija prima

- Makedonska rodna

- Balkanija

- Makedonska rana

- Improved Orovchanka

- Kralica (Queen)

- Vulkan (Volcano)

- Amazon

- Simonida

- Mojson

From this financial aspect, one can absolutely observe the increase of investments in the agricultural sector, which has a constant and significant growth, and this is the reason for the growth of the production quality.

Figure 5. Allocated IPARD funds in regard to the GDP within agriculture by years,

State Statistical Office

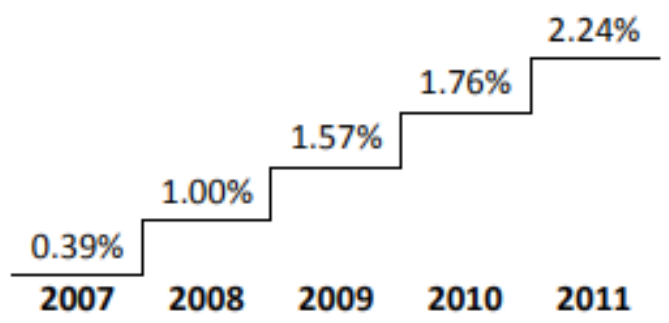

Source: Kovachev, 2013

The President of the Agro-Business Chamber emphasized that the innovative approach in the development of the internationally recognized wheat varieties is what moves them forward and maintains them all these years. A novelty is that from 2019, for the 
first time two Macedonian varieties of wheat and one variety triticale created in one of the leading companies will be added in the European catalog of varieties, which means that the grains can be sold in European Union countries, which is an additional factor that would contribute to the obvious increase of the role of agriculture in the increase of the GDP of our country.

It is a matter of the varieties

- "Ostaka", which is recognized in the Republic of Greece, the Republic of Serbia and the Republic of Bulgaria, and

- "Triticale", recognized and demanded in the Republic of Serbia and the Republic of Bulgaria. (Denar, 2019)

From the abovementioned it can be concluded that the production of wheat, and other cereal crops in general, is a very important branch in the national economy of the Republic of North Macedonia. Due to this fact, constant support for the producers of cereal crops is needed, that is, financial support in order to improve the production (purchase of new and modern machinery, purchase or rent of new arable land, visits to agricultural fairs in the country and abroad), but also support from science that will include the creation of new varieties that will provide higher yields and will be more resistant to diseases. In addition, the support from science should be based on continuous education of producers, aimed at proper cultivation of of cereal crops, timely response to the emergence of diseases, proper use of means of protection, as well as familiarization with new varieties and their advantages compared to the other varieties. All of this will have a significant contribution in the increase of the domestic production, reduced import, and possibility for export, which in any case will have a favorable impact on the national economy of the Republic of North Macedonia (Hadzi Naumova-Mihajlovska et al., 2018).

\section{Conflict of interests}

The authors declare no conflict of interest.

\section{References}

1. Agrounija, (2019), Retrived from: https:/www.agrounija.com.mk/ (10 ${ }^{\text {th }}$ August 2021)

2. Agricultural Market Information System, (AMIS), downloaded data from Annual Reports on the price of agricultural products from 2017, 2018, 2019, and 2020, Retrived from: http://zpis.gov.mk/

3. Annual Agricultural Report 2015, https://www.stat.gov.mk/pdf/2021/5.1.21.03 mk.pdf

4. Bender, D,A., Bender, A, E. (1999). Benders' Dictionary of Nutrition and Food Technology. $7^{\text {th }}$ edition. Woodhead Publishing, Abington. 
5. Darrell Smith R., Smith K,A. (2003). Country Study for Biodiversity of the Republic of Macedonia (First National Report). Publisher: Ministry of Environment and Physical Planning. Skopje. Republic of Macedonia

6. Denar, MK (2019, may 30). https://denar.mk/205287/ekonomija/dve-makedonskisorti-pcenici-za-prv-pat

7. Food and Agriculture Organisation (FAO). (2002). World Agriculture: Towards 2015/2030. Summary Report. FAO, Rome. Italy

8. Hadzi Naumova-Mihajlovska, K., Daniloska, N., Boskovska, D. (2018). Agricultural subsidies in Republic of Macedonia and their impact on sector development. Economic Development, 3, 69-82. UDC 338.432.5(497.7)

9. Kovachev, G. (2013). Research for improving the efficiency and effectiveness in the allocation of funds from the IPARD program (public policy document). Center for Economic Analyses (CEA), Skopje, Republic of Macedonia.

10. McKevith, B., 2004. Nutritional aspects of cereals. Nutrition Bulletin, 29, 111-142.

11. National program for agriculture and rural development 2007-2013. (2007). Operational programme under the EU instrument for pre-accession for rural development (IPARD). Skopje, Republic of Macedonia.

12. Republic of North Macedonia, (2014) National strategy for agriculture and rural development for the period 2014-2020, Retrived from: http://www.mzsv.gov.mk/ CMS/Upload/docs/NSZRR2014-2020.pdf (10th December 2020)

13. Statistical Office - MakStat - http://www.stat.gov.mk/Default.aspx

14. Zelena Berza (In English: green stock market) (2016, july 14). https://zelenaberza. com.mk/novite-makedonski-sorti-pchenica-poprinosni-i-pokvalitetni/ 